\title{
IMPLEMENTASI TUGAS DAN WEWENANG MAJELIS RAKYAT PAPUA MENURUT UNDANG-UNDANG NOMOR 21 TAHUN 2001 TENTANG OTONOMI KHUSUS PAPUA
}

\author{
Anggun Putri Priyani \\ Universitas Muslim Indonesia
}

\begin{abstract}
This research intended to know the implementation of task and obligation of MRP obediently to the mandate of the law Number 21 of 2001 on Special Autonomy for Papua Province. This research did intended to know the protection of MRP to the basic righs of Papua indigenous, and the factors that influence the MRP in carrying out its duties and authority.This research was conducted by tracing the regulation and various literatures that has relation to this writing and interview with some source person of gaining input in order to perfecting this thesis writing.In order to implement special autonomy in Papua, it was formed MRP that is a the cultural representative of Papua indigenous, that has certain authority in the pace of protecting the Papua indigenous' right, underlying to the esteem to the esteem to the custom and culture, female outsourcing, and the consolidation of religious life concordance. The results of this research showed that : 1) The implementation of the tasks and obligation of the MRP have not been conducted conseguently and consistently. The result, MRP has not fully give protection to the basic right of Papua indegenous. 2) the slowness of Provincial Government and DPRP in forming special regional regulation that rule on operational technique of the implementation of task and obligation of MRP and some duties and autorities of MRP that is amended in the article 20 paragraph (1) in Law Number 21 of 2001 on Special Autonomy to Papua Province, there are only (2) that could be implemented,i.e. the consideration and approval toward the candidate of Governor and Vice Governor nominees that was proposed by DPRP, and consideration and approval of MRP to the special regional regulation that was formed by Governor along with DPRP. Keywords: Special Autonomy, Papua Society Council (MRP), Right Of Papua Indigeous.
\end{abstract}

Abstrak

Penelitian bertujuan untuk mengetahui impelmentasi tugas dan wewenang MRP sesuai amanat Undang-Undang Nomor 21 Tahun 2001 Tentang Otonomi Khusus bagi Provinsi Papua. Penelitian ini juga bertujuan mengetahui perlindungan MRP terhadap hak-hak dasar orang asli Papua. Faktor-faktor yang mempengaruhi MRP dalam melaksanakan tugas dan wewenangnya.Penelitian ini 
dilakukan dengan cara menelusuri peraturan perundang-undangan dan berbagai literature yang ada kaitannya dengan penulisan tesis ini, dan wawancara dengan beberapa narasumber untuk mendapatkan masukan guna penyempurnaan penulisan tesis ini.Dalam rangka penyelenggaraan otonomi khusus di Papua dibentuk Majelis Rakyat Papua yang merupakan representasi kultural orang asli Papua, yang memiliki wewenang pada penghormatan terhadap adat dan budaya,pemberdayaan perempuan,dan pemantapan kerukunan hidup beragama.Hasil penelitian ini menunjukkan bahwa : 1) Implementasi tugas dan wewenang MRP belum dapat dilaksanakan secara konsekuen dan konsisten. Akibatnya MRP belum sepenuhnya memberikan perlindungan terhadap hak-hak dasar orang asli Papua.2) lambatnya Pemerintah Provinsi dan DPRP membentuk perdasus yang mengatur teknis operasional dalam pelaksanaan tugas dan wewenang MRP yang diamanatkan pada pasal 20 ayat (1) Undang-Undang Nomor 21 Tahun 2001 tentang Otonomi Khusus Bagi Provinsi Papua, ayat (2) yang dapat dilaksanakan yaitu pertimbangan dan persetujuan terhadap bakal calon Gubernur dan Wakil Gubernur yang diusulkan oleh DPRP, dan pertimbangan dan persetujuan MRP terhadap perdasus yang dibentuk oleh Gubernur bersama DPRP. Kata Kunci : Otonomi Khusus, Majelis Rakyat Papua, Hak-hak Orang Asli Papua.

\section{PENDAHULUAN}

Jatuhnya rezim order baru pada tahun 1998 memberikan peluang untuk menata kembali kehidupan politik, ekonomi dan hukum. Tuntutsn tersebut kemudian dikenal dengan tuntutan reformasi yang menjadi tuntutan masyarakat adalah perubahan system pemerintahan dari sentralistik menjadi pemberintahan yang demokratis dengan prinsip desentralisasi. Dalam rangka pemerintahan yang berprinsip pada desentralisasi/otonomi daerah, maka ditetapkan beberapa perangkat hukum dibidang politik, diantaranya adalah Undang-Undang Nomor 32 Tahun 2004 tentang Pemerintahan Daerah.

Undang-undang Nomor 32 Tahun 2004, merupakan hasil reformasi sekaligus juga merupakan wujud nyata adanya kemauan dan komitmen pemerintah untuk melakukan penataan dan perubahan terhadap segala aspek yang menyangkut kepentingan dan proses pembagunan daerah. Otonomi Daerah juga merupakan salah satu landasan hukum bagi daerah untuk melaksanakan pembagunan daerah yang lebih aspiratif berdasarkan prakarsa sendiri,dengan memanfaatkan seluruh potensi yang dimilikinya.

Undang-undang Nomor 32 Tahun 2004 Tentang Pemerintahan Daerah, bagi Provinsi Papua, dinilai belum sepenuhnya mengakomodir seluruh kepentingan daerah. Karakterikstik daerah yang sangat berbeda dengan beberapa daerah lain di wilayah Negara Kesantuan Republik Indonesia. Permasalahan- permasalahan 
yang belum terselesaikan, mengharuskan adanya perlakuan khusus bagi Provinsi Papua.

Pola pendekatan pemerintah daerah yang bersifat sentralistik dilaksanakan sejak bergabunya Irian Jaya ( sekarang Papua) dalam wilayah Negara Kesatuan Republik Indonesia pada tahun 1963, belum memberikan arti dan makna sesungguhnya bagi masyarakat Papua sebagai bagian dari warga Negara Indonesia. Perlakuan dan tindakan diskriminatif masih sering dirasakan, hak-hak dasar masyarakat asli Papua sering terabaikan, sehingga kesejahteraan dan kemakmuran masyrakat asli Papua belum tercapai. Penanganan dan penyelesaian berbagai permasalahan yang timbul lebih sering menggunakan pendekatan keamanan atau stabilitas dari pada pendekatan social atau kesejahteraan, yang mengedepankan asas kesetaraan dan keragaman kehidupan sosial budaya masyarakat asli Papua. Dalam kenyataan seperti ini, kondisi rakyat Papua sangat memprihatinkan terutama dibidang pendidikan, kebudayaan, social ekonomi dan politik masih sangat tertinggal dibandingkan dengan masyarakat di provinsi lainnya.

Kondisi yang terjadi di tanah Papua menumbuhkan kesadaran bahwa tanggung jawab dan fungsi negara hukum belum menyentuh kehidupan masyarakat asli Papua. Ironisnya pada alenia keempat Pembukaan Undang Undang Dasar Negara Republik Indonesia menentukan ;

"Kemudian daripada itu untuk membentuk suatu Pemerintah Negara Indonesia yang melindungi segenap bangsa Indonesia dan seluruh tumpah darah Indonesia dan untuk memajukan kesejahteraan umum, mencerdaskan kehidupan bangsa,dan ikut melaksanakan ketertiban dunia yang berdasarkan kemerdekaan, perdamaian abadi dan keadilan sosial".

Sehubungan dengan hal tersebut juga, dalam rumusan Pasal 18B UndangUndang Dasar 1945 ayat (1) dan ayat (2) menentukan :

"(1) Negara mengakui dan menghormati satuan-satuan pemerintahan daerah yang bersifat khusus atau bersifat istimewa yang diatur dengan Undang-Undang.

“(2) yang Negara mengakui menghormati kesatuan-kesatuan masyarakat hukum adat beserta hak-hak tradisionalnya sepanjang masih hidup dan di sesuaikan dengan perkembangan masyarkat dan prinsip Negara Kesatuan Republik Indonesia yang diatur dalam Undang-Undang”.

Kondisi yang terjadi di tanah Papua, memunculkan kekecewaan dan ketidakpuasan rakyat Papua terhadap pemerintah, yang kemudian memicu munculnya aspirasi untuk melepaskan diri sebagai bagian dari Republik Indonesia. Tuntunan "merdeka" menjadi fenomena yang tidak terbendung dan bergema diseluruh pelosok tanah Papua. Menyadari arti pentingnya keutuhan wilayah Negara Kesatuan Republik Indonesia dimasa yang akan dating, 
menumbuhkan pemikiran baru bagi terselesainya masalah-masalah mendasar yang dihadapi pemerintah daerah dan rakyat Papua. Keinginan pemerintah untuk menangani permasalahan di Provinsi Papua secara eksplisit tertuang dalam ketetapan MPR-RI Nomor IV/MPR/1999 tentang GBHN tahun 1999-2004. Dalam Bab IV huruf g angka 2 ditegaskan bahwa dalam rangka mengembangkan otonomi daerah dalam wadang Negara Kesatuan Republik Indonesia, serta untuk menyelesaikan secara adil dan menyeluruh permasalahan di daerah yang memerlukan penanganan segera dan sungguh- sungguh, maka perlu di tempuh langkah-langkah sebagai berikut :

1. Mempertahankan integrasi bangsa di dalam wadah Negara Kesatuan Republik Indonesia dengan tetap menghargai kesetaraan dan keragaman kehidupan social budaya masyarakat Irian Jaya melalui penetapan daerah otonomi khusus yang diatur dengan undang-undang.

2. Menyelesaikan kasus-kasus pelanggaran Hak Asasi Manusia di Irian Jaya melalui proses pengadilan yang jujur dan bermartabat.

Dalam ketetapan MPR-RI Nomor IV/MPR/2000 tentang rekomendasi kebijakan dalam penyelenggaraan otonomi daerah, yang antara lain menekankan tentang pentingnya segera merealisasikan otonomi khusus tersebut melalui penetapan suatu undang-undang khusus bagi Provinsi Irian Jaya dengan memperhatikan aspirasi masyarakat.

Undang-Undang No 21 Tahun 2001 Tentang Otonomi Khusus bagi Provinsi Papua, ( Lembaran Negara Republik Indonesia Tahun 2001 Nomor 135, Tambahan Lembaran Negara Republik Indonesia Nomor 4151) merupakan suatu kebijakan yang bersifat strategis, dalam rangka peningkatan pelayanan umum, akselerasi pembagunan, dan pemberdayaan seluruh rakyat di Provinsi Papua terutama orang asli Papua. Kebijakan bersifat khusus ini, sekaligus merupakan komitmen pemerintahan untuk mengatasi dan mengurangi kesenjangan social dan pembangunan antara Provinsi Papua dengan provinsi-provinsi lainnya diwilayah Negara Kesatuan Republik Indonesia. Hal ini memberikan peluang bagi orang asli Papua dan masyarakat secara aktif sebagai subyek utama dalam seluruh proses penyelenggaraan pemerintahan dan pelaksanaan pembangunan dan penikmat hasil bangunan.

Otonomi khusus bagi Provinsi Papua pada dasarnya adalah pemberian wewenang yang lebih luas bagi Provinsi dan rakyat Papua untuk mengatur dan mengurus diri sendiri di dalam karangka Negara Kesatuan Republik Indonesia. Wewenang yang lebih luas berarti pula tanggungjawab yang lebih besar bagi Provinsi dan rakyat Papua, untuk menyelenggarakan pemerintah dan mengatur pemanfaatan kekayaan alam di Provinsi Papua untuk sebesar-besarnya bagi 
kemakmuran rakyat Papua sebagai bagian dari rakyat Indonesia sesuai dengan peraturan perundang-undangan. Wewenang ini berarti pula wewenang untuk memberdayakan potensi social budaya dan perekonomian masyarakat Papua, termaksuk memberikan peran yang memadai bagi orang-orang asli Papua melalui para wakil adat,agama,dan kaum perempuan. Peran yang dilakukan adalah ikut serta merumuskan kebijakan daerah, menentukan kehidupan rakyat Papua,melestarikan budya serta lingkungan alam Papua,yang tercermin melalui perubahan nama Irian Jaya menjadi Papua, lambing daerah dalam bentuk bendera daerah, dan lagu daerah sebagai bentuk aktualisasi jati diri rakyat papua dan pengakuan terhadap eksistensi hak ulayat,adat,masyarakat adat dan hukum adat.

Sebagai pengejewatan dari adanya kebijakan tersebut diatas maka didalam Undang-undang Otonomi Khusus Papua diamanatkan pembentukan Majelis Rakyat Papua (MRP). MRP pada hakekatnya merupakan salah satu lembaga politik formal (struktur politik) di tingkat Provinsi. MRP berkedudukan sebagai representasi kultural orang asli Papua yang memeliki wewenang tertentu dalam rangka perlindungan hak-hak orang asli Papua dengan berlandaskan pada penghormatan terhadap adat dan budaya, pemberdayaan perempuan, dan pemantapan kerukunan hidup beragama.

Pembentukan MRP ini di latarbelakangi oleh beberapa alasan :

1. Hak-hak politik orang asli Papua dan kaum perempuan cenderung diabaikan;

2. Representasi politik orang asli Papua dan kaum perempuan di lembagalembaga politik (parpol/legislatif) tidak cukup signifikan;

3. Aspirasi politik orang asli Papua dan kaum perempuan cenderung tidak terkodinir;

4. Tikat partisipasi politik orang asli Papua dan kaum perempuan tergolong relatif rendah;

5. Komitmen untuk menghormati adat dan budaya, memberdayakan kaum perempuan, dan memantapkan kerukunan hidup beragama;

6. Komitmen untuk melakukan rekonsiliasi antara sesama orang asli Papua, maupun oran asli Papua dengan sesame penduduk di Provinsi Papua.

Lembaga adat yang direflesikan sebagai lembaga legislatif masyarakat asli Papua adalah Majelis Rakyat Papua yang selanjutnya disebut MRP yang anggotaanggotanya terdiri dari perwakilan unsur agama,unsur adat, dan unsur perempuan sebagai representasi kultural masyarakat adat asli Papua, sebagaimana diamanatkan dalam Undang-undang Nomor 21 Tahun 2001 Tentang Otonomi Khusus bagi Provinsi Papua Bab V Bagian kesatu Pasal 5 ayat (2) yang merumuskan : "Dalam rangka penyelenggaraan otonomi khusus di Papua 
dibentuk MRP ysng merupakan representasi kultural orang asli Papua dengan berlandaskan pada penghormatan terhadap adat dan budaya, pemberdayaan perempuan dan pemantapan kerukunan hidup beragama".

Berpedoman pada peraturan Pemerintah Nomor 54 Tahun 2004 Tentang tata cara pemilihan anggota Majelis Rakyat Papua (lembaran Daerah Provinsi Papua Tahun 2005 Nomor 7), proses pembentukan dan pemilihan anggota MRP akhirnya dapat diselesaikan. Pada tanggal 31 Oktober 2005 Mentri Dalam Negeri melantik 42 anggota MRP yang terdiri dari unsur adat 14 orang, unsur agama 14 orang dan unsur perempuan 42 orang.

Dengan demikian keberadaan MRP ini sungguh-sungguh membawa makna dan manfaat social bagi orang asli Papua terutama terkait dengan upaya peningkatan kualitas hidup dan kesejahteraan orang asli Papua itu sendiri. Undang-undang Nomor 21 Tahun 2001 tentang Otonomi Khusus bagi Provinsi Papua, Pasal 20 Ayat (1) mengatur tugas dan wewenang Majelis Rakyat Papua (MRP), yang meliputi :

a. Memberikan pertimbangan dan persetujuan terhadap bakal calon Gubernur dan Wakil Gubernur yang diusulkan oleh DPRP;

b. Memberikan pertimbangan dan persetujuan terhadap calon anggota Majelis Permusyawaratan Rakyat Republik Indonesia utusan daerah Provinsi Papua yang diusulkan oleh DPR;

c. Memberikan spertimbangan dan persetujuan terhadap rancangan Perdasus yang diajukan oleh DPRP bersama-sama dengan Gubernur;

d. Memberikan saran, pertimbangan dan persetujuan terhadap rencana perjanjian kerjasama yang dibuat oleh Pemerintah maupun Pemerintah Provinsi dengan pihak ketiga yang berlaku di Provinsi Papua khusus yang menyangkut perlindungan hak-hak orang asli Papua;

e. Memperhatikan dan penyaluran aspirasi, pengaduan masyarakat adata, umat beragama, kaum perempuan dan masyarkat pada umumnya yang menyangkut perlindungan hak-hak orang asli Papua, serta memfasilitasiti tindak lanjut penyelesaian dan;

f. Memberikan pertimbangan kepada DPRD Kabupaten/kota serta Bupati/Walikota mengenai hal-hal yang terkait dengan perlindungan hakhak orang asli Papua”.

Tugas dan wewenang yang melekat pada MRP hanya dapat dilaksanakan dengan baik jika seseorang anggota MRP tidak cukup bebekal status sebagai wakil masyarakat, tetapi harus juga memiliki kemampuan-kemampuan seperti (Semule A,2003:70): 
1. Memahami dengan baik masalah, tantangan dan peluang pembangunan orang-orang asli Papua dalam kaitannya dengan konteks social politik local, nasional dan global, sehingga mampu dengan seksama menguji Rancangan-Rancangan Perdasus yang dimaksudkan oleh DPRP dan Gubernur, hanya dengan memiliki kemampuan seperti MRP bias dengan tepat dan taktis menerima,menolak, atau menerima rancangan perdasus yang dimksudkan itu diperbaiki.

2. Memiliki kemampuan berdiplomasi dan berintegritas, terutama ketika harus membahas hal-hal sensitive, seperti soal lambing-lambang Provinsi Papua (bendera dan lagu), penyelesaian masalah-masalah HAM, klarifikasi sejarah Papua dalam NKRI, perlindungan HAM, pelaksanaan kewenangan-kewenangan pemerintah pusat di Provinsi Papua dengan kekhususan,dan sebagainya.

3. Mampu untuk mendengar,menampung dan mengolah masukan, saran, keluhan, bahkan protes yang disampaikan oleh para konstituen untuk diteruskan ke pihak-pihak yang berkompeten, dan memastikan bahwa hal-hal tersebut benar-benar di tindaklanjuti. Selain itu, setiap anggota MRP harus mampu pula untuk menjelaskan dengan baik dan benar setiap keputusan yang diambil sehingga rakyat sungguh-sungguh merasa bahwa suara merdeka telah didengar, dan bahwa mereka secara substansial dilibatkan dalam setiap proses pengembalian keputusan yang berdampak pada kehidupan mereka.

Berdasarkan uraian singkat diatas, maka penulis berpendapat penting untuk mengadakan penelitian tesis mengenai tugas dan wewenang Majelis Rakyat Papua sesuai amanat Otonomi Khusus Papua, dengan judul : "IMPLEMENTASI TUGAS DAN WEWENANG MAJELIS RAKYAT PAPUA MENURUT UNDANG-UNDANG NOMOR 21 TAHUN 2001 TENTANG OTONOMI KHUSUS PAPUA".

\section{METODE PENELITIAN}

Permasalahan yang telah dirumuskan di atas akan dijawab atau dipecahkan dengan menggunakan metode pendekatan yuridis empiris. Pendekatan yuridis (hukum dilihat sebagai norma karena dalam membahas permasalahan penelitian ini menggunakan bahan bahan hukum.

Jadi, pendekatan yuridis empiris dalam penelitian ini maksudnya adalah bahwa dalam menganalisis permasalahan dilakukan dengan cara memadukan bahan-bahan hukum (yang merupakan data sekunder) dengan data primer yang diperoleh di lapangan yaitu tentang pelaksanaan Tugas dan Wewenang Majelis 
Rakyat Papua Menurut Undang-Undang No 21 Tahun 2001 Tentang Otonomi Khusus Papua.

\section{PEMBAHASAN}

A. Impelementasi Tugas dan Wewenang Majelis Rakyat Papua sesuai Amanat Undang-undang No 21 Tahun 2001 Tentang Otonomi Khusus Papua.

MRP memiliki tugas dan wewenang yang terbatas dan secara jelas telah diatur dalam Undang-Undang Nomor 21 Tahun 2001, pasal 20, sebagaimana telah dijelaskan. Tugas dan wewenang tersebut, dilaksanakan berlandaskan pada Perdasus. Penyusunan perdasus harus mengacu pada Peraturan Pemereintah No.64 Tentang MRP. Secara eksplit diatur mekanisme pelaksanaan tugas dan wewenang MRP, sebagaimana tertuang dalam pasal 37 sampai pasal 41, Peraturan Pemerintah Nomor 64 Tahun 2008 yang dirumuskan :

1. Pelaksanaan tugas dan wewenang MRP dalam hal memberikan pertimbangan dan persetujuan terhadap pasangan bakal calon Gubernur dan Wakil Gubernur yang diusulkan oleh DPRP.

Adapun tata cara pelaksanaan tugas dan wewenang sebagaimana dimaksud, adalah sebagai berikut :

a. MRP memberikan pertimbangan dan persetujuan terhadap bakal calon Gubernur dan Wakil Gubernur.

b. Pertimbangan dan persetujuan sebagaimana dimaksud ayat (1) hanya menyangkut persyaratan pasangan bakal calon Gubernur dan Wakil Gubernur adalah orang asli Papua.

c. Hasil pertimbangan dan persetujuan MRP, diberitahukan kepada pimpinan DPRP paling lambat 7 (tujuh) hari sejak tanggal pengajuan.

d. Apabila pasangan bakal calon tidak mendapatkan persetujuan MRP karena tidak memenuhi persyaratan sebagaimana dimaksud dalam ayat (2), DPRP diberi kesempatan untuk memperbaiki persyaratan pasangan bakal calon paling lambat 7 (tujuh) sejak saat pemberitahuan dari MRP.

e. Pasangan bakal calon yang telah mendaptkan persetujuan MRP disampaikan kepada DPRP.

f. Apabila dalam waktu 7 (tujuh) hari,MRP tidak memberikan persetujuan terhadap bakal calon yang diajukan DPRP, pasangan bakal calon tersebut sah diajukan menjadi pasangan calon.

2. Pelaksanaan tugas dan wewenang MRP dalam hal memberikan pertimbangan dan persetujuan terhadap rancangan perdasus. 
Tata cara pemberian pertimbangan dan persetujuan sebagaimana dimaksud sebagai berikut :

a. Rancangan perdasus disampaikan oleh Pemerintah Provinsi bersama DPRP kepada MRP untuk dilakukan pembahasan guna mendapat pertimbangan dan persetujuan.

b. Pembahasan rancangan perdasus sebagaimana dimaksud pada ayat (1) dilakukan oleh kelompok kerja paling lama 30 (tiga puluh) hari sejak diterimanya rancangan perdasus.

c. Dalam memberikan pertimbangan dan persetujuan sebagaimana dimaksud,MRP melakukan konsultasi dengan pemerintah provinsi dan DPRP.

d. Dalam hal rancangan perdasus tidak mendapatkan pertimbangan dan persetujuan lebih dan 30 (tiga puluh) hari, maka rancangan perdasus dianggap telah mendapat pertimbangan dan persetujuan oleh MRP.

e. Pemerintah Provinsi bersama DPRP menetapkan perdasus sebagaimana dimaksud tersebut menjadi perdasus.

3. Pelaksanaan tugas dan wewenang dalam hal memberikan saran, pertimabangan dan persetujuan terhadap rencana perjanjian kerjasama dengan pihak ketiga.

Tata cara memberikn saran, pertimbangan dan persetujuan sebagaimana dimaksud adalah sebagai berikut :

a. Rencana perjanjian kerja sama dengan pihak ketiga disampaikan oleh Pemerintah atau Pemerintah Provinsi bersama DPRP kepada MRP untuk mendapat pertimbangan khusus menyangkut perlindungan hak-hak orang asli Papua.

b. Pembahasan rencana perjanjian kerja sama dengan pihak ketiga sebagaimana dimaksud pada ayat (1) dilakukan oleh kelompok kerja yang membidangi untuk mendapatkan persetujuan rapat pleno MRP selambatlambatnya 30 (tiga puluh) hari sejak diterimanya rencana perjanjian.

c. Apabila diperlukan kelompok kerja dapat berkonsultasi kepada Pemerintah atau Pemerintah Provinsi mengenai rencana perjanjian kerja sama dengan pihak ketiga sebagaimana dimaksud pada ayat (1).

d. Dalam hal rencana perjanjian kerja sama dengan pihak ketiga tidak mendapatkan pertimbangan dan persetujuan lebih dari 30 (tiga puluh) hari sebagaimana dimaksud pada ayat (2), rencana perjanjian kerja sama dengan pihak ketiga dianggap telah mendapat pertimbangan dan persetujuan MRP. 
e. Perjanjian kerja sama dengan pihak ketiga dari luar negeri dilaksanakan sesuai dengan peraturan perundang-undangan yang mengatur hubungan luar negeri.

B. Faktor- faktor yang mempengaruhi Tugas dan Wewenang Majelis Rakyat Papua dalam pelaksanaan Undang-undang No 21 Tahun 2001 Tentang Otonomi Khusus Papua

1. Subtansi hukum (legal substance)

Substansi juga berarti produk yang dihasilkan oleh orang yang berada dalam sistem hukum yang mencakup keputusan yang mereka keluarkan, aturan baru yang mereka susun. Substansi juga mencakup hukum yang hidup (living law), bukan hanya aturan yang ada dalam kitab undang-undang (law books). Idealnya tatanan hukum nasional mengarah pada penciptaan sebuah tatanan hukum nasional yang bisa menjamin penyelenggaraan negara dan relasi antara warga negara, pemerintah dan dunia internasional secara baik. Tujuan politik hukum yaitu menciptakan sebuah sistem hukum nasional yang rasional, transparan, demokratis, otonom dan responsif terhadap perkembangan aspirasi dan ekspektasi masyarakat, bukan sebuah sistem hukum yang bersifat menindas, ortodoks dan reduksionistik.

a. Hambatan Yuridis

Ditinjau dari proses penetapan dasar hukum, pembentukan Majelis Rakyat Papua memang mengalami penundaan cukup lama, Undangundang No 21 Tahun 2001 Tentang Otonomi Khusus Papua bagi provinsi Papua di tetapkan pada tanggal 21 November 2001, dan efektif berlaku pada tanggal 1 Januari 2002. Sebagaimna di amanatkan dalam Undangundang No 21 Tahun 2001 Bab V bagian kesatu pasal 5 ayat (2) yang menegaskan: Dalam rangka penyelenggaraan Otonomi Khusus di Provinsi Papua dibentuk Majelis Rakyat Papua yang rnerupakan representasi kultural orang asli Papua yang memiliki kewenangan tertentu dalam rangka perlindungan hak-hak orang asli Papua, dengan berlandaskan pada penghormatan terhadap adat dan budaya, pemberdayaan perempuan, dan pemantapan kerukunan hidup beragama.

Khusus bagi Provinsi Papua menegaskan : "Pemekaran Provinsi Papua menjadi provinsi-provinsi dilakukan atas persetujuan MRP dan DPRP setelah memperhatikan dengan sungguh-sungguh kesatuan social budaya, kesiapan sumberdaya manusia, dan kemampuan ekonomi dan perkembangan dimasa dating" 
Pasal 74 Undang-undang Otonomi Khusus Papua menegaskan : "Semua peraturan perundang-undangan yang ada dinyatakan tetap berlaku di Provinsi Papua sepanjang tidak diatur dalam Undang-Undang ini."

Atas dasar situasi konflik tersebut, MRP-RI menetapkan Keputusan Nomor 5/MRP/2003, pada lampiran angka 1 tentang politik dan keaman, pada huruf $b$ yang mengatur mengenai Papua, ditegaskan sebagai berikut.

1) Majelis menyarankan kepada pemerintah dan DPR untuk menata kembali perturan perundang-undangan yang menyangkut otonomi dan pemekaran Papua termaksud peninjauan kembali Undang-undang No 45 Tahun 1999 dan Inpres No 1 Tahun 2003 untuk disesuaikan denga isi,jiwa dan semangat Undang-undang No 21 Tahun 2001.

2) Melaksanakan Undang-undang No 21 Tahun 2001 secara utuh,konsekuen, komperhensif, dengan mempercepat proses penyusunan tersebut terutama pembentukan Majelis Rakyat Papua, dalam waktu selambat-lambatnya 1 (satu) tahun.

Berpedoman pada Peraturan Pemerintah No 64 Tahun 2008 dan Peraturan Daerah Provinsi Papua No 4 Tahun 2008, proses pembentukan dan pemilihan anggota MRP akhirnya dapat di selesaikan. Dengan begitu di tambah lagi dengan pemerintah provinsi belum juga membentuk perdasus yang mendukung pelaksanaan tugas dan wewenang MRP, sehingga tujuan utama pembentukan lembaga MRP yaitu memperjuangkan dan melindungi hak-hak orang asli Papua dengan sepenuhnya di laksanakan oleh MRP.

Penulis berpendapat, lamban dan lambatnya penyusunan peraturan perundang-undangan pelaksanaan Undang-undang No 21 Tahun 2001 Tentang Otonomi Khusus Papua juga sekaligus menunjukkan bahwa sesungguhnya kita sementara menyianyiakan kesempatan dan peluang untuk merancang sendiri hamper semua askpek pembangunan, pemerintah dan kemasyrakatan agara sedapat mungkin sesuai dengan kekhasan social budaya, politik dan ekonomi di Papua.

\section{Struktur Hukum (legal structure)}

Dalam teori ini sruktural hukum yang menentukan bisa atau tidaknya hukum itu dilaksanakan dengan baik. Kewenangan lembaga penegak hukum dijamin oleh Undang-undang. Sehinggga dalam melaksanakan tugas dan tanggung jawabnya terlepas dari pengaruh-pengaruh lain. Terdapat Adagium yang menyatakan "Fiat justicia et pereat mundus". Meskipun dunia runtuh hukum harus di tegakan. Hukum tidak dapat berjalan baik atau tegal apabila tidak adapa aparat hukum yang kredibilita, kompeten dan independen. Sebera 
bagus nya suatu peraturan perundang undangan bila tidak didukung dengan aparat penegeak hukum yang baik maka keadilan hanya angan-angan.

\section{Hambatan Operasional.}

Belum adanya Perdasus yang mengatur atau yang berfungsi sebagai instrument hukum operasional untuk menjadi dasar pelaksanaan tugas dan wewenang, sangat mempengaruhi efektifitas dan kinerja MRP dalam melaksanakan tugas dan wewenangnya sebagai lembaga represntasi kultural orang asli Papua. Secara normatif MRP di harapkan dapat berperan secara aktif dan dapat memberikan hasil kerja yang optimal untuk kepentingan keberpihakan, pemberdayaan, dan perlindungan terhadap hak-hak orang asli Papua. Di samping terhadap kepntingan penduduk Papua secara keseluruhan.

Dengan ketiadaan instrument hukum yang mengatur tugas dan wewenang serta hak dan kewajiban MRP sebagaimana di kemukakan diatas membawa serta pengaruh terhadap pola hubungan kerja antara lembaga pemerintah daerah di provinsi Papua. Seharunya MRP sebagai lembaga resmi pemerintah daerah sangat perlu mempunyai pedoman yang jelas dan pasti tentang pola hubungan kerja antara Gubernur, DPRP,MRP serta para Bupati/Walikota dan DPRD di Tanah Papua. Sampai sekarang MRP seolaholah berjalan sendiri dan terjadinya ketidakseimbangan hubungan kerja antara lembaga-lembaga tersebut di atas.

\section{Budaya Hukum (legal culture)}

sikap manusia terhadap hukum dan sistem hukum-kepercayaan, nilai, pemikiran, serta harapannya. Kultur hukum adalah suasana pemikiran sosial dan kekuatan sosial dan yang menentukan bagaiman hukum digunakan, dihindari, atau disalahgunakan. Budaya hukum erat kaitannya dengan kesadaran hukum masyarakat. Semakin tinggi kesadaran hukum masyarakat maka akan tercipta budaya hukum yang baik dan dapat merubah pola pikir masyarakat mengenai hukum selama ini. Secara sedrhana, tingkat kepatutan masyarakatt terhadap hukum merupakan salah satu indikator berfungsinya hukum.

\section{PENUTUP}

\section{A. Kesimpulan}

Berdasarkan pembahasan diatas maka, disimpulkan sebagai berikut :

1) Implementasi Tugas dan Wewenang Majelis Rakyat Papua dalam kenyataannya kurang efektif.

2) Faktor-faktor yang mempengaruhi Implementasi Tugas dan Wewenang Majelis Rakyat Papua adalah sebagai berikut : Kurangnya keseriusan dari 
Pemerintah untuk menetapkan peraturan yang berkaitan dengan MRP, yang dinilai sebagai sikap setengah hati pemerintah memberikan status Otonomi Khusus kepada Papua dan kurangnya Perdasus yang mengatur atau yang berfungsi sebagai instrument Hukum opersional untuk menjadi dasar pelaksanaan tugas dan wewenang MRP.

\section{B.Saran}

1) Pemerintah Provinsi Papua harus secepatnya menetapkan Peraturan Daerah Khusus (Perdasus) yang mengatur pelaksanaan tugas dan wewenang MRP, sebagaimana diamanatkan dalam pasal 20 Undang-undang No 21 Tahun 2001. 


\section{DAFTAR PUSTAKA}

A. Buku

Antoh, Demmy. Menggugat Implementasi Otsus Papua, Pusat Pengkajian Pembangunan Papua. Sorong, 2008.

Azhari. Negara Hukum Indonesia. UI-Press, 1995.

Agus Sumule. Mencari Jalan Tengah Otonomi Khusus Papua. Jakarta: Gramedia Pustaka Utama, 2003.

Badan Penelitian dan Pengembangan Daerah Provinsi Papua, Laporan Akhir Studi Peluang dan Kendala dalam Melakukan Investasi di Provinsi Papua, Jayapura, 2005.

Dalam H.A.K. Pringgodigdo,Tiga Undang-Undang Dasar,Cet. Ke-5. Jakarta: PT. Pembangunan, 1981.

Edi toe Hendarto. Negara Kesatuan Desentralisasi, Federalisme. Jakarta: Graha Ilmu dan Universitas Pancasila pers, 2009.

Kemitraan, Nilai-nilai Dasar Orang Papua Dalam Mengelola Tata Pemerintahan (Governance): Studi Refleksif Antropologis, Partnership for Governance Reform Centre for Learning and Advancing Experimental Democracy Indonesia Forestry and Governance Institute, Jakarta, 2012.

Manan Bagir. Menyongsong Fajar Otonomi Daerah. Pusat Studi Hukum (PSH), Fakultas Hukum UII Yogyakarta, 2001.

Musa'ad. A.M. Penguatan Otonomi Daerah Dibalik Bayang-Bayang Ancaman Disintegrasi, Pusat Kajian Demokrasi (Democratic Center), Jayapura: Universitas Cendrawasi, 2005.

B. Peraturan Perundang-Undangan

Undang- undang Republik Indonesia Tahun 1945.

Undang-undang Nomor 23 Tahun 2014 Tentang Pemerintahan Daerah.

Undang-undang Nomor 21 Tahun 2001 Tentang Otonomi Khusus. Papua.

Peraturan Pemerintah No.64 Tahun 2008 Tentang Majelis Rakyat Papua.

Peraturan Daerah Khusus No 5 Tahun 2008 Tentang Kedudukan Protokoler Pimpinan dan Anggota Majelis Rakyat Papua,

Peraturan Daerah Khusus No 4 Tahun 2008 Tentang Pelaksanaan Tugas Dan wewenang Majelis Rakyat papua. 